\title{
Nigella sativa EXTRACT IMPROVES SEMINIFEROUS TUBULE EPITHELIAL THICKNESS IN LEAD ACETATE-EXPOSED BALB/C MICE
}

\author{
Alis Nur Diana ${ }^{1}$, Reny l'tishom ${ }^{2}$, Sri Agus Sudjarwo ${ }^{3}$ \\ ${ }^{1}$ Master of Reproductive Health Science, ${ }^{2}$ Department of Medical Biology, ${ }^{3}$ Department of Pharmacology, \\ Faculty of Medicine, Airlangga University, Surabaya
}

\begin{abstract}
ABSTRAK
Timbal yang masuk ke dalam tubuh dapat menyebabkan peningkatan produksi ROS (Reactive Oxygen Species) yang dapat mempengaruhi sistem reproduksi. Ekstrak jintan hitam (Nigella sativa) mengandung antioksidan tinggi yaitu tymoquinone dapat digunakan untuk menekan stres oksidatif yang diinduksi timbal pada hewan percobaan. Penelitian ini bertujuan untuk membuktikan ekstrak jintan hitam (Nigella sativa) dalam memperbaiki peningkatan tebal epitel tubulus seminiferus pada mencit Balb/c yang dipapar timbal $(\mathrm{Pb})$ asetat. Rancangan penelitian menggunakaan posttest only control group design. Subyek penelitian mencit jantan (Mus musculus) Balb/c sejumlah 30 ekor, dibagi menjadi 5 kelompok. Kelompok K-: kelompok kontrol tanpa pemberian timbal asetat dan ekstrak jintan hitam, kelompok $\mathrm{K}+$ : kelompok dengan pemberian timbal asetat $50 \mathrm{mg} / \mathrm{KgBB}$ selama $28 \mathrm{hari}$, kelompok P1: kelompok perlakuan dengan pemberian timbal asetat $50 \mathrm{mg} / \mathrm{KgBB}$ selama 28 hari + ekstrak jintan hitam $0,3 \mathrm{mg} / \mathrm{gBB}$ selama 21 hari, kelompok P2: kelompok perlakuan dengan pemberian timbal asetat $50 \mathrm{mg} / \mathrm{Kg} B \mathrm{~B}$ selama 28 hari + ekstrak jintan hitam 0,6 mg/gBB selama 21 hari, dan kelompok P3: kelompok perlakuan dengan pemberian timbal asetat $50 \mathrm{mg} / \mathrm{gBB}$ selama 28 hari + ekstrak jintan hitam 1,2mg/gBB selama 21 hari. Hasil penelitian menunjukkan rerata \pm standar deviasi tebal epitel tubulus

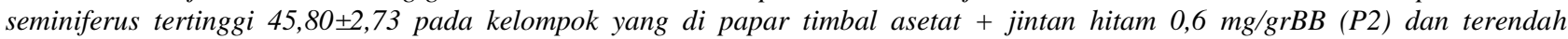
$32,75 \pm 4,07$ pada kelompok yang di papar timbal asetat $(K+)$. Kemudian di analisis dengan uji Anova dengan hasil ada perbedaan secara signifikan tebal epitel tubulus seminiferus antara P1, P2, P3 dengan K+. Kesimpulan penelitian ini adalah pemberian ekstrak jintan hitam terbukti dapat memperbaiki peningkatan tebal epitel tubulus seminiferus mencit (Mus musculus) Balb/c yang dipapar timbal $(\mathrm{Pb})$ asetat. (FMI 2017;53:180-184)
\end{abstract}

Kata kunci: Timbal asetat; jintan hitam; tebal epitel tubulus seminiferus

\begin{abstract}
Lead that enters the body may lead to increased production of ROS (Reactive Oxygen Species) that may affect reproductive system. Black cumin (Nigella sativa) extract contains high antioxidant, tymoquinone, that may be used to suppress oxidative stress induced by lead in animal experiments. This study aimed to prove that black cumin (Nigella sativa) extract improves the thickness of seminiferous tubular epithelium in Balb/c mice exposed to lead $(\mathrm{Pb})$ acetate. This study used post-test only control group design. The subjects in this study were 30 Balb/c male mice (Mus musculus), divided into 5 groups. K-group: control group without lead acetate and black cumin extract, $K+$ group: group with $50 \mathrm{mg} / \mathrm{kgBW}$ of lead acetate for 28 days, P1 group: treatment group with 50 $\mathrm{mg} / \mathrm{kgBW}$ of lead acetate for 28 days $+0.3 \mathrm{mg} / \mathrm{gBW}$ of black cumin extract for 21 days, P2 group: treatment group with $50 \mathrm{mg} / \mathrm{kgBW}$ of lead acetate for 28 days $+0.6 \mathrm{mg} / \mathrm{gBW}$ of black cumin extract for 21 days, and P3 group: treatment group with $50 \mathrm{mg} / \mathrm{gBW}$ of lead acetate for 28 days $+1.2 \mathrm{mg} / \mathrm{gBW}$ black cumin extract for 21 days. The results showed that the mean \pm standard deviation of the highest thickness of seminiferous tubular epithelium was $45.80 \pm 2.73$ in the group that was exposed to acetate $+0.6 \mathrm{mg} / \mathrm{gBW}$ of black cumin (P2), and the lowest was $32.75 \pm 4.07$ in the group that was exposed to lead acetate $(K+)$. The results were then analyzed by Anova test. The results showed that there was significant differences in the thickness of seminiferous tubular epithelium between P1, P2, P3 and K+. In conclusion, black cumin extract administration was proved to improve the thickness of seminiferous tubular epithelium in lead $(\mathrm{Pb})$ acetate-exposed Balb/c mice (Mus musculus). (FMI 2017;53:180-184)
\end{abstract}

Keywords: Lead acetate; black cumin; thickness of seminiferous tubular epithelium

Correspondence: Alis Nur Diana, Master of Reproductive Health Science, Faculty of Medicine, Airlangga University, Jalan Prof Dr Moestopo 47, Surabaya 60131. Telp: 031-5501617. Email: alisnurdiana@ gmail.com

\section{INTRODUCTION}

Indonesia is ranked fifth in lead-polluted countries according to Political and Economic Risk Consultancy (PERC) Ltd, after India, China, Vietnam and the Philippines. Lead in the form of alkyl-Pb compound is used as a mixture in gasoline that serves as anti-knock (Kawatu 2008). Traffic congestion is one of the biggest contributor of air pollution, resulting in motor vehicle emissions of $66.34 \%$ out of total pollution, whereas industrial activity is $18.90 \%$, settlement is $11.12 \%$ and waste is $3.68 \%$ (Riyadina 1997). Lead may enter the 
body through various ways, such as respiration, gastrointestinal tract and skin contact (Laila \& Sofwati 2013). Acute poisoning caused by lead is uncommon, but long-term (chronic) exposure to lead may cause a variety of disorders. In male reproductive system, the low amount of lead and cadmium may interfere with male fertility (Mayo 2005, Telisman 2000).

When lead enters the body, 99\% will bind to red blood cells and inhibit ALAD (delta-Aminolevulinic Acid Dehydratase) which causes ALA (Aminolevulinic) to increase, and the end result is an increase in ROS production. According to Flora et al (2012), increased production of ROS and decreased antioxidant reserves may cause oxidative stress. The increased production of ROS is a result of exposure to lead that has been identified in the lungs, endothelial tissue, liver and brain, testes and sperm (Hsu \& Guo 2002). The lack of antioxidant level or the presence of antioxidant enzyme activity constraints cause oxidative stress, and they may damage or kill cells (Hayati 2011).

Several studies showed that the various antioxidants contained in herbal plant extracts may be used to suppress the oxidative stress which was induced by lead in animal testings. Herbal plant extract primarily acts as free radical cleanser, forms a metal complex (metal chelation), and stabilizes the membrane system (AbdelRaheem 2010). One plant that contains high antioxidants is black cumin (Nigella sativa). Black cumin seeds contain fixed and essential oils, proteins, alkaloids and saponins. However, the most noticeable biological activity of this seed is thymoquinone. Thymoquinone is known to be a source of antioxidants (Ali \& Blunden 2003). In addition, black cumin oil also contains high fatty acids that may increase the activity of 17 betahydroxisteroid dehydrogenase enzyme which is one of the enzymes that is involved in testosterone synthesis (Maneesh \& Jayaleksmi 2006). Thus, further research about the benefits of black cumin as natural source of antioxidants to improve the thickness of seminiferous tubular epithelium in lead $(\mathrm{Pb})$ acetate-exposed $\mathrm{Balb} / \mathrm{c}$ mice (Mus musculus) is needed.

\section{MATERIALS AND METHODS}

This study was a pure experimental study using post-test only control group design. This study was conducted at Pharmacology, Anatomic Pathology, and Medical Biology Laboratories, Faculty of Medicine, Airlangga University from September to December, 2016. This study obtained the certificate of Ethical Benefit from Faculty of Medicine, Airlangga University. The samples used in this study were male mice (Mus musculus) aged \pm 3 months, weight: \pm 30 grams, and healthy, characterized by agile movement and good appetite. Tested animals were acclimatized by being caged for one week.

The study samples were 30 mice divided into 5 groups. The first group as negative control group consisted of mice that was feed and treated with solvent from lead acetate and black cumin extract. The second group as a positive group was treated using $50 \mathrm{mg} / \mathrm{kgBW}$ of lead. The third group as treatment group I was treated using $50 \mathrm{mg} / \mathrm{kgBW}$ of lead and $0.3 \mathrm{mg} / \mathrm{gBW}$ of black cumin extract. The fourth group as treatment group II was treated using $50 \mathrm{mg} / \mathrm{kgBW}$ of lead and $0.6 \mathrm{mg} / \mathrm{gBW}$ of black cumin extract. The fifth group as treatment group III was treated using $50 \mathrm{mg} / \mathrm{kgBW}$ of lead and 1.2 $\mathrm{mg} / \mathrm{gBW}$. Lead was given through feeding tube once a day for 28 days. Black cumin extract was given through feeding tube for 21 days started from 15th to 35th day. Mice were sacrificed using ether. Each mice was incised on the abdominal wall and its testes were taken. The testes were stored in pots filled with formalin. Furthermore, histologic preparations were made with 56 micro thickness, and front, middle and back section were taken, so there were three preparations for one testis of male mice. The preparations were examined under microscope with six visual fields in one preparation using 400x magnification and expressed in the thickness of seminiferous tubules. The thickness of seminiferous tubule was measured from the edge toward the lumen in $\mu \mathrm{m}$ unit.

Measurement data comprised mean, standard deviation (SD) of minimum and maximum values, normality test data using Kolmogorov Smirnov test and the analysis used one-way Anova. The results were significant if $\mathrm{p}<0.05$. To determine which groups differed significantly, a Least Significant Difference (LSD) analysis was performed.

\section{RESULTS}

In this study, the thickness of semulusiferus tubules was normal. Data of mean tubular seminiferous epithelial thicknesses were presented in the form of mean as presented in Table 1.

Table 1 shows that the thickness of seminiferous tubular epithelium in positive $(+)$ control group treated using lead acetate $(\mathrm{K}+)$ is thinner than that in non-lead acetate group (K-). In the groups treated using lead acetate and black cumin (P1, P2, P3), the seminiferous tubule epithelium thicknesses were thicker than that in positive control group treated using lead acetate $(\mathrm{K}+)$. The thicknesses of seminiferous tubular epithelium in P1 group and P3 were thinner than that in K-. Whereas, 
P2's tubular epithelium was thicker than that in K-. In P1 group, the seminiferous tubular epithelium was thinner than that in $\mathrm{P} 2$ group and thicker compared to $\mathrm{P} 3$. Seminiferous tubular epithelium in $\mathrm{P} 2$ was the thickest compared to P1 and P3, whereas, that in P3 was the thinnest.

Table 1. Data of seminiferous tubular epithelium thicknesses between groups after black cumin (Nigella sativa) extract administration in Balb/c mice exposed to lead acetate

\begin{tabular}{cccccc}
\hline Samples & Mean & SD & Min & Max & p value \\
\hline K- & $42.80^{\text {ac }}$ & 5.06 & 36.82 & 49.73 & $<0.001$ \\
K+ & $32.75^{\text {b }}$ & 4.07 & 26.70 & 37.12 & \\
P1 & $41.50^{\text {ac }}$ & 2.98 & 37.41 & 45.78 & \\
P2 & $45.80^{\mathrm{a}}$ & 2.73 & 40.79 & 48.60 & \\
P3 & $39.30^{\mathrm{c}}$ & 3.31 & 33.37 & 42.07 & \\
\hline
\end{tabular}

Note: Different superscipt in the same column showed significant differences based on multiple comparative test $(\mathrm{p}<0.05)$

The statistical test using the one-way Anova test showed that $p<0.05$, so there was a significant difference in the thickness of seminiferous tubular epithelium in overall groups (K-, K+, P1, P2, P3) after black cumin (Nigella sativa) extract administration at Balb/c mice exposed to lead acetate. Mean thickness of tubular seminiferous epithelium is presented in the form of the mean values shown in Fig. 1 and Fig. 2.

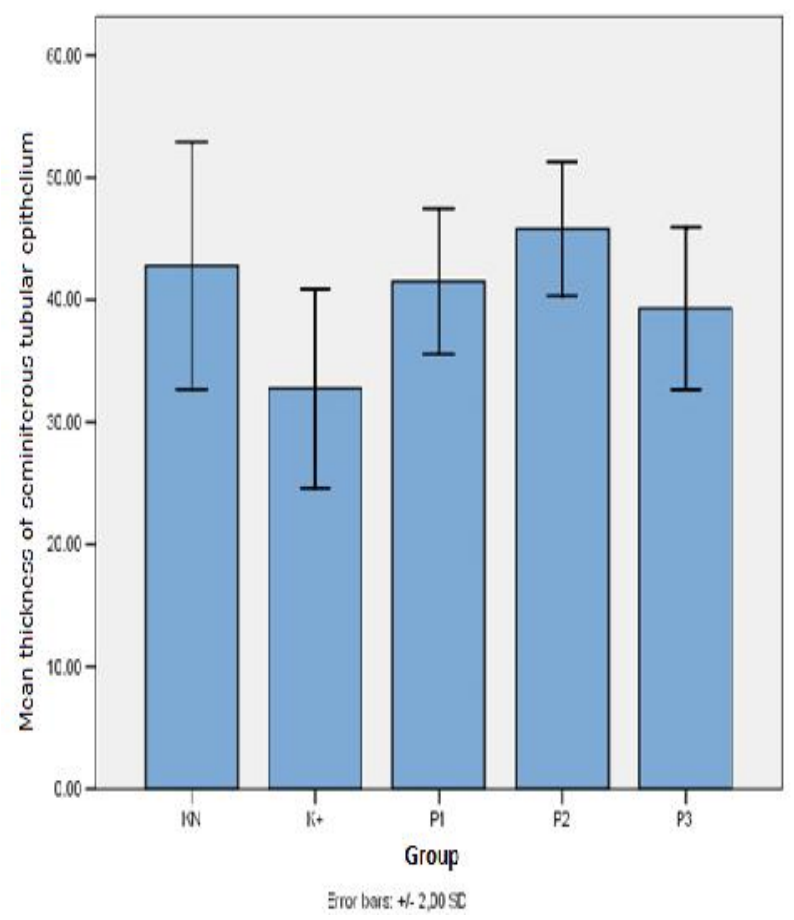

Fig. 1. Mean thickness of seminiferous tubular epithelium in $\mathrm{K}-, \mathrm{K}+, \mathrm{P} 1, \mathrm{P} 2$, and $\mathrm{P} 3$ groups.

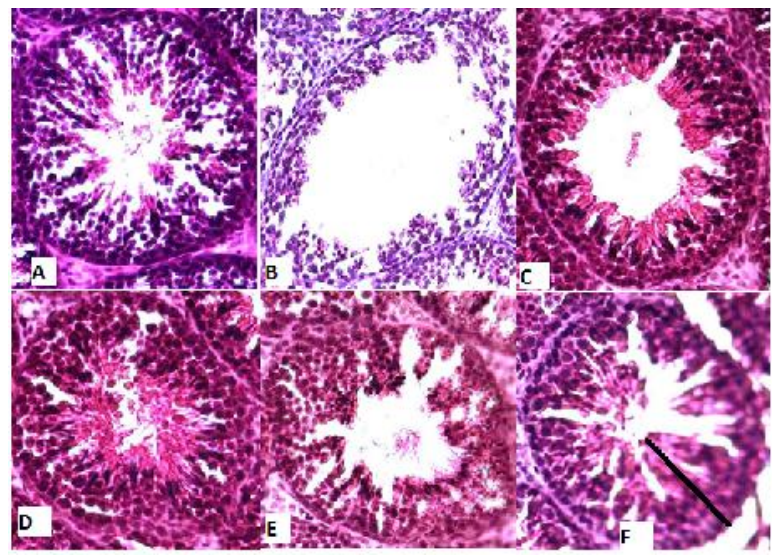

Fig. 2. Cross-section of seminiferous tubules: (A) untreated group, (B) group induced by 50 $\mathrm{mg} / \mathrm{kgBW}$ lead acetate, (C) group induced by $50 \mathrm{mg} / \mathrm{kgBW}+0.3 \mathrm{mg} / \mathrm{gBW}$ black cumin extract, (D) group induced by $50 \mathrm{mg} / \mathrm{kgBW}$ lead acetate $+0.6 \mathrm{mg} / \mathrm{gBW}$ black cumin extract, (E) group induced by $50 \mathrm{mg} / \mathrm{kgBW}$ lead acetate $+1.2 \mathrm{mg} / \mathrm{gBW}$ black cumin extract, (F) thickness measurement of seminiferous tubular epithelium.

\section{DISCUSSION}

The results of this study indicated that there were differences in the thickness of seminiferous tubular epithelium between negative control group (K-), positive control group $(\mathrm{K}+)$ exposed to acetate lead, and treatment groups treated with $0.3 \mathrm{mg} / \mathrm{grBW}(\mathrm{P} 1), 0.6$ $\mathrm{mg} / \mathrm{grBW}(\mathrm{P} 2)$, and $1.2 \mathrm{mg} / \mathrm{grBW}$ (P3) black cumin extract. $\mathrm{K}+$ showed a decrease in the thickness of seminiferous tubular epithelium as compared to K-. Lead exposure may lead to the formation of free radicals. The administration of lead acetate may decrease the thickness of seminiferous tubule epithelium. The thickness decrease in seminiferous tubular epithelium is due to the large number of germ cells, Sertoli cells, and missing spermatogenic cells. The decrease of seminiferous tubule tickness is due to the loss of germ cells as a result of lead induction (Madiha et al 2014). Increased radical formation due to lead induction may decrease reserves of endogenous antioxidants that may cause oxidative stress. Oxidative stress may result in mitochondrial damage that regulates the mechanism of apoptosis. Excessive apoptosis in testes triggers damage and degeneration of seminiferous tubules. Apoptosis is caused by the release of cytochrome-C protein (as a result of ROS invading in inner and outer membranes of mitochondria). Cytochrome- $\mathrm{C}$ is secreted by an increase in $\mathrm{Ca} 2+$. The increase in $\mathrm{Ca} 2+$ is caused by membrane permeability failure due to reactions occurring in ROS towards lipids and protein 
membranes (Lamando et al 2014). In addition to being characterized by the release of $\mathrm{C}$-cytochrome protein, lead induction may enhance caspase-3 expression. Increased caspase-3 expression provides clues that testicular cells undergo excessive apoptosis.

In this study, the administration of $50 \mathrm{mg} / \mathrm{kgBW}$ lead acetate for 28 days might decrease the thickness of seminiferous tubular epithelium. Other studies have also shown similar results that lead might reduce testicular weight, and the presence of seminiferous tubular degeneration was characterized by the absence of spermatogenic cells in tubular lumen and the increased caspase-3 expression (Elgawish \& Abdelrazek 2014). A study conducted by Moniem et al (2010) showed that lead exposure caused degeneration and damage of seminiferous tubules.

The decrease of seminiferous tubular epithelium thickness occurred in positive control group rather than in negative control group. This was also caused by the deterioration of Leydig cells due to oxidative stress. Another mechanism that may cause a decrease of seminiferous tubular epithelium thickness is the presence of toxic effects on lead that may cause hypothalamus disorder. Lead is considered to suppress the secretion of GnRH produced by hypothalamus by blocking norepinephrine (Sokol et al 2002). Decreased GnRH secretion results in decreased LH and FSH secretion. LH stimulates Leydig cells to produce testosterone, in which testosterone is required for spermatogenic cell development and FSH stimulates Sertoli cells to produce androgen binding protein (ABP) to bind testosterone and enhance spermatogonium development. The presence of decreased testosterone and FSH has an effect on the testicular structure, such as diameter of seminiferous tubules and spermatogenic cells (Apriliani et al 2013).

The administration of black cumin (Nigella sativa) extract may increase the thickness of seminiferous tubular epithelium in mice exposed to lead acetate. The results showed differences between treatment groups treated with $0.3 \mathrm{mg} / \mathrm{gBW}, 0.6 \mathrm{mg} / \mathrm{gBW}, 1.2 \mathrm{mg} / \mathrm{gBW}$ black cumin, negative control, and positive control. The administration of $0.6 \mathrm{mg} / \mathrm{gBW}$ black cumin extract showed that the thickness of seminiferous tubular epithelium was higher when compared with $\mathrm{K}-, \mathrm{K}+, \mathrm{P} 1$, and P3 groups.

Antioxidants have two action mechanisms which are as a primary antioxidant and as a secondary antioxidant. The secondary function of antioxidants is to slow down the rate of autocesidation by various mechanisms outside the autooxidation chain breaking mechanism. If the primary antioxidant $(\mathrm{AH})$ is added with the low concentration, it will inhibit or prevent the autooxidation reaction of fats and oils. The addition may inhibit oxidation reactions at initiation and propagation stages. The antioxidant radicals $\left(\mathrm{A}^{*}\right)$ formed in the reaction are relatively more stable and do not have adequate energy to react with other lipid molecules to form new lipid radicals (Iswara 2010). Conversely, the administration of antioxidants at high concentration will actually turn these antioxidants into pro-oxidants. These antioxidants no longer function as an antidote to free radicals. The process of antioxidants turned into pro-oxidants is as follows:

$$
\begin{aligned}
& \mathrm{AH}+\mathrm{O} 2 \text {----------------------> } \mathrm{A} *+\mathrm{HOO}^{*} \\
& \mathrm{AH}+\mathrm{ROOH} \text {----------------> RO}{ }^{*}+\mathrm{H} 2 \mathrm{O}+\mathrm{A}^{*}
\end{aligned}
$$

The results of this study indicated that the dose of 0.3 $\mathrm{mg} / \mathrm{grBW}$ (P2) black cumin extract was effective to increase the thickness of seminiferous tubular epithelium in Balb/c mice exposed to lead acetate. The 1.2 $\mathrm{mg} / \mathrm{gBB}$ black cumin extract may decrease the thickness of seminiferous tubular epithelium in Balb/c mice exposed to lead acetate.

\section{CONCLUSION}

Black cumin (Nigella sativa) extract improves the thickness of seminiferous tubular epithelium in Balb/c mice exposed to lead acetate.

\section{REFERENCES}

Abdel-Raheem IT (2010). Greentea Ameliorates Renal Oxidative Damage Induced By Gentamicin In Rats. Pak Journal Pharmaceutical Science, 21-28

Apriliani M, Nurcahyani N, Busman H (2013). Efek pemaparan kebisingan terhadap jumlah sel-sel spermatogenik dan diameter tubulus seminiferus mencit (Mus musculus L.), Seminar Nasional Sains \& Teknologi V, Lampung, Lembaga Penelitian Universitas Lampung

Elgawish RAR, Abdelrazek HMA (2014). Effect of lead acetate on testiscular function and caspase- 3 expression with respect to the protective effect of cinnamon in albino rats. Toxicology Reports 1, 795-801

Flora G, Gupta D, Tiwari A (2012). Toxicity Of Lead: A review with recent updates. Interdiscipline toxicology 5, 47-58

Hayati A (2011). Spermatologi. Surabaya: Pusat Penerbitan Dan Percetakan Unair

Hsu PC, Guo YL (2002). Antioxidant Nutrients and Lead Toxicity. Toxycology 180: 33-34.

Iswara RAFW (2010). Pengaruh pemberian ekstrak daun cyclea barbata L. miers terhadap motilitas 
spermatozoa mencit balb/c jantan yang dipapar asam rokok. Artikel Karya Tulis Ilmiah. Denpasar, Universitas Udayana

Kawatu PAT (2008). Kadar Timbal Darah, Hipertensi, Dan Perasaan Kelelahan Kerja Pada Petugas Stasiun Pagi Siang Bahan Bakar Umum Di Kota Manado. Tesis. Yogyakarta, Universitas Gadjah Mada

Lamando D, Soegianto A, Abadi A, Keman S (2014). Antioxidant effects of sarang semut (myrmecodia pendans) on the apoptosis of spermtogenic cells of rats exposed to plumbum. Research Journal of Pharmaceutical, Biological and Chemical Sciences 5, 282-294

Laila NN, Shofwati I (2013). Kadar timbal darah dan keluhan kesehatan pada operator wanita SPBU. Jurnal Kesehatan Reproduksi 4, 41-49

Madiha M, Makhlouf M, Eldien HMS, et al (2008). The effect of lead acetate on testiscular structure and protective effect of vitamin E in Adult Albino Rat. Journal of Histology 31, 406-418
Maneesh M, Jayaleksmi H (2006). Role of reactive oxygen species and antioxidants on pathophysiology of male reproduction. International Journal Clinical Biochemistry 21, 80-89

Mayo (2005). Diseases and Conditions; Infertility. Mayo Foundation $\mathrm{f}$ or Medical Education and Research (MFMER), December 07; 1-3. Available from: http://www.cnn.com/HEALTH/library/DS/00310.html.

Riyadina W (1997). Pengaruh Pencemaran Pb terhadap Kesehatan. Pusat penelitian Penyakit Tidak Menular. Badan Penelitian dan Pengembangan Kesehatan Depkes RI. Jakarta.

Sokol RZ, Wang S, Wan YJ, et al (2002). Long-term, low-dose lead exposure alters the gonadotropinreleasing hormone system in the male rat. Environmen Health Perspective 110, 871-874 